\title{
Do Cash Holdings Differ in Europe and Asia Pacific?
}

\author{
Ummar Aftab*, Waseem Akhter Qureshi ${ }^{* *}$ and Attiya \\ Yasmin Javid ${ }^{* * *}$
}

\begin{abstract}
This paper identifies the determinants that contribute towards the variation in financial assets that make up a firm's total cash reserves, specifically in two important regions of the world i.e. Asia Pacific and Europe. The findings of the research reveal that firms in the region of Asia Pacific have slightly higher cash holdings, as compared to firms in Europe. Moreover, the study also identifies that the elevated cash holdings in Asia Pacific are not a result of the agency problem, as is generally viewed, rather, the shareholder power hypothesis is a more appropriate measure to elucidate this elevation in the level of cash holdings in the region. When shedding light on to the firm specific cash holding determinants, the findings of the research reveal that leverage, dividend payment, profitability, growth and net working capital, cash flows and financial strength, influence cash reserves in both the regions, exactly in the same manner. This shows the application of transaction, and precautionary motives in both the regions. The study further identifies that size, and investments have a varying effect in both the regions that are taken into consideration. Again, this difference may be attributed to Shareholders' Power Hypothesis, specifically for Asia Pacific and the Agency View, specifically for Europe. Shareholders' Right Index influences cash reserves in Asia Pacific in a positive manner, while in Europe, the same index shows a negative influence. The development in the financial markets has a negative negatively influence on cash holdings in Asia Pacific, and a positive one in Europe.
\end{abstract}

Keywords: Cash holdings, formal institutions, firm specific determinants, Asia Pacific, Europe.

JEL classification: G20, G23, G39.

\footnotetext{
${ }^{*}$ PhD Scholar, Capital University of Science and Technology, Islamabad, Pakistan.

${ }^{* *}$ PhD Scholar, Capital University of Science and Technology, Islamabad, Pakistan.

${ }^{* * *}$ Head of Department, Department of Economics, PIDE Islamabad, Pakistan.
} 


\section{Introduction}

Generally, firms that dwell in perfect capital markets are easily able to generate funds at insignificant costs, due to which, the decision to hold cash is irrelevant. In such markets, the value of the firms is not affected by any changes in their liquid assets. However, literature reveals that in the real markets, firms prefer, as well as tend to make investments in short term assets. For example, Al-Najjar and Belghitar (2011) find that firms in the United Kingdom hold cash, and other cash equivalents including treasury bills, marketable securities, and commercial papers etc., as $9 \%$ of their total assets. Gao, Harford and Li (2013) identify that the share of cash reserves in total assets of the firms in the United States of America is 18.8 $\%$. Kato, Lee and Skinner (2011) examine that the contribution of cash in the total assets of the Japanese firms, is only $10 \%$. Rehman and Wang (2015) find that cash happens to be about $6.67 \%$ of the total assets in China. This shows that the markets are not perfect, and the firms consider cash holding an important strategic decision.

The decision of the firms to hold cash reserves is explained by the Agency Theory, and the Shareholders' Power Hypothesis, albeit differently. The Agency Theory assumes that the managers of the firms are prone to maximize efforts in lieu of their own interests at the cost of those of the shareholders. Jensen (1986) argues that the presence of free cash flows aggravates the situation, as managers use free cash flows at their discretion. This may harm the due benefits to the shareholders, and hence, the cash reserves of the firm may be artificially reduced in order to increase their value. On the other hand, as per the Shareholders' Power Hypothesis, the shareholders allow greater cash holdings to the management when their interests are sufficiently secured.

There are several studies that analyze cash holding determinants, specifically for factors that pertain to firms (Bates, Kahle \& Stulz, 2009; Lins, Servaes \& Tufano, 2010; Ozkan \& Ozkan, 2004). Moreover, other studies identify the impact of formal institutions on cash holdings, along with the firm specific variables also applicable in this case as well (Chen, Dou, Rhee, Truong \& Veeraraghavan2015; Kalcheva \& Lins, 2007; Pinkowitz, Stulz \& Williamson, 2015). Some studies reveal a significant relationship between formal institutions and the cash reserves (Chen et al.,2015; Ferreira \& Vilela, 2004; Kalcheva \& Lins, 2007), while some other studies were unable to find a substantial influence of institutional factors, on the level of cash reserves (Pinkowitz et al., 2015). 
Although, the above-mentioned studies examine the effect of different firm specific, as well as national level variables, in the context of corporate cash holdings, there is no cross region study found in the literature, which sheds light on the determination of cash reserves in Asia pacific and Europe. This is an endeavor that is undertaken in order to bridge the gap between studies on single country or region, and cross region comparative studies, by investigating a broader set of firm specific factors, such as the size, z-score, dividend, profitability, leverage, intangibles, investments, net working capital, cash flows and institutional factors including overall country governance, Shareholders' Right Index and capital markets development in two important regions of the world i.e. Asia Pacific and Europe.

Both regions are different in their pattern of treating cash holdings, solely due to the reason that there is a difference in the governance systems that prevail in different countries of the regions in question, and/or the agency and asymmetric problems at the firm level. This study also aims to find which factors are more pronounced in elucidating the differences of cash reserves in both the regions. If it is assumed that a higher level of cash holdings is indicative of an asymmetry problem of the firm (Myer, 1984), the countries in Asia Pacific region suffer more from this, as the median cash holdings of Asia Pacific are $11.22 \%$, as compared to $9.49 \%$ of those in Europe (Table-A2). Our study, however, reveals that cash holdings in Asia Pacific region are driven more by the Shareholders' Power Hypothesis, whereas the Agency View is more rigorously followed in Europe. Nevertheless, other theories like the Financial Hierarchy Theory and the Tradeoff Theory are also applicable in both the regions.

The formal institutions used in this study make use of the worldwide governance, shareholder right index, market capitalization percentage of GDP, and the domestic credit provided by financial institutions as a percentage of the GDP. The results reveal that in Europe and the Asia Pacific region, formal institutions tend to play a lesser important role in formulating the cash holding decision. On the contrary though, firm specific factors significantly influence the decision to hold cash, and cash equivalents in both the said regions. Furthermore, it must be noted that in the regions under the consideration of this study, cash flows and financial strength influence the cash reserves positively; while net working capital, leverage, growth, profitability and dividend are negatively associated with cash reserves. The study also comes to the conclusion that investments, as well as the size have a positive influence on cash reserves in Asia, but have a significantly negative effect in Europe. 
This study helps to fathom, as well as understand the behavior of firms, specifically towards their decision to hold cash reserves in Asia Pacific and Europe - which happen to have different institutional settings than the rest of the world, as well as in comparison to each other. The time period of this study is concentrated between the years of 2007 and 2016. The main purpose of the research was to study the impact of the company specific factors, as well as the institutional cash holding factors influencing the 4,662 companies, from 35 countries that are categorized under the Asia Pacific region and Europe. In exact terms, there were 3,358 firms from Asia Pacific, and 1,304 firms from Europe, that were taken into consideration in this research. Thus, this paper analyzes the decisions to hoard cash, and cash equivalents in a more holistic and all encapsulating range of business and corporate culture within the two regions that are in question. This study is one of the pioneer studies which aim to focus on company specific, and institutional factors that affect cash holding decisions and activities in Asia Pacific and Europe, thus providing guidance to finance practitioners and academic scholars.

This paper has been constructed in the following scheme: In section 2 , the theory on cash holding determinants, along with the empirical base is presented; in section 3, the hypothesis development, sample, data and variables are stated; the results are explained in section 4; and the summary of the study is described in section 5 .

\section{Corporate Cash Holdings: Theory and Empirical Base}

In this section, theories related to the cash holding determinants are presented. Following this, then, the literature review is presented, which refers to other important studies previously carried out, specifically pertaining to the relationship between firm specific and institutional factors, and cash holdings in different economies of the world.

\subsection{Literature Review}

The Trade-off theory states that when the marginal benefits of cash holdings equate with the marginal costs of cash reserves, a firm's value is at its highest level. The advantages of hoarding cash reserves include reduction in transaction costs, lesser probability of financial distress, and more chances to successfully execute investment plans (Guizani, 2017). The main cost that is associated with hoarding cash is the opportunity cost that comes with it. When opportunity and fund raising costs are higher, the 
firms are inclined towards holding more cash (Dittmar, Mahrt-Smith \& Servaes, 2003; Miller \& Orr, 1966).

The Pecking order theory, on the other hand, states that firms pursue financial hierarchy so that the asymmetry information costs may be reduced (Myers \& Majluf, 1984). At the first instance, in order to finance investments, firms use internal resources, and after these resources are exhausted, external means of financing are utilized. Different investment and financing decisions are determined by this hierarchal pattern of financing, and cash reserves are merely the result of such decisions (Dittmar et al., 2003).

As per Jenson (1986), in case of negative net present value (NPV) projects, entrenched managers desire to stockpile cash for their discretionary uses, rather than distributing free cash flows to shareholders. These free cash flows in the hands of managers are reserved for their private benefits. As per Dittmar et al. (2003), firms having more agency issues tend to hoard more cash reserves. According to Dittmar and Smith (2007), and, Harford, Mansi and Maxwell (2012), in the firms where managers have excess cash holdings, entrenched managers are likely to spend cash quickly.

\subsection{Empirical Evidence}

In the previous years, there have been several studies on cash holdings, not only in developed, but also in many developing countries of the world. Among the developed countries, researches of Al-Najjar and Belghitar (2011) use the data that was extracted from the UK; Opler, Pinkowitz, Stulz and Williamson (1999) analyze cash holding determinants for American firms; while Teruel and Solano (2008) work on Spanish SME firms. These studies use only firm specific factors that influence cash holdings.

Other than the above-mentioned researches, there are also cross countries studies that were conducted on cash holding determinants. For example, for EMU countries, Ferreira and Vilela (2004) analyze the influence of financial variables on cash reserves. Dittmar et al. (2003) identify the relationship between corporate governance, and cash holdings for 45 countries. For Brick countries i.e. Brazil, Russia, India and China, Al-Najjar (2013) investigate the relationship between firm specific factors, and cash holdings. Pinkowitz et al. (2015) compare cash holding decisions of US firms, with their foreign counterparts. Guney, Ozkan and Ozkan (2003) analyze cash holding determinants for France, USA, Germany and Japan. 
Furthermore, Almeida, Campello and Weisbach (2004), identify that for constrained firms, cash flows from operations tend to be more sensitive, while the unconstrained firms show no sensitivity in this regard. When agency problems show no signs of ease, the outside investors discount the value of their cash reserves (Kalcheva \& Lins, 2007). Foley, Hartzell, Titman and Twite (2007), analyze the behavior of cash holdings for US multinational firms, which also have to take the rules of taxation into consideration. Their results indicate that the level of repatriation tax is positively related with cash holdings.

The review of above literature reveals that not only firm specific factors influence cash holding decision of the firms, but formal institutions also have a pronounced impact on the level of cash that is held by firms. There are studies that pertain to a single country, as well as on the situation that prevails across countries. Having taken all these factors into consideration, and also taking into account the author's scope of study in this regard, not a single study is found in the literature, which makes a comparison of cash holding behavior between Europe and Asia pacific.

\section{Methodology and Data}

In section 3.1, the conceptual framework and hypothesis are presented, followed by the empirical specification in section 3.2. In section 3.3, sample, data and variables are discussed, respectively.

\subsection{Conceptual Framework and Hypotheses Development}

The literature reveals that not only firm specific variables affect cash holding decisions, but institutional factors also influence the level of cash which firms hold. In this section, the hypotheses are developed for both types of variables, separately.

\subsubsection{Firm Specific Determinants of Cash Holdings}

In a perfect capital market, a firm's value is not affected by the financial decisions that are taken by the management (Stiglitz, 1974). Also, decision to hold cash reserves have no impact on the firm's true value (Opler et al., 1999). However, in reality, the markets are imperfect, so impotence of holding cash, and cash equivalents in the economy, cannot be overlooked (Al-Najjar, 2013). On the basis of prior studies, this study identifies the factors affecting cash reserves across two important regions i.e. Asia pacific and Europe, as under: 


\subsubsection{Firm Size}

In all studies on cash holdings, the firm size is used as an important determinant which may be used to fathom the level of cash that is held by these firms. There are some studies which identify that firm size, and cash holdings are positively related with each other (Lins et al., 2010; Qiu \& Wan, 2015). It is also supported by all the major theories, as large firms have the ability to obtain external finance at lower costs as compared to smaller firms; so, larger firms have a lesser need to hold cash reserves.

Nevertheless, as per Ozkan and Ozkan (2004) and, Liu, Mauer and Zhang (2014), the firm size influences cash reserves of the firms, in a negative manner. Furthermore, as per the Shareholder Power Hypothesis, the management of the larger firms may be allowed, by shareholders, to hold more cash reserves when their interests are sufficiently protected. The larger firms are subject to more scrutiny, and external discipline and thus, the information asymmetry is reduced. In the light of the above statements, the first hypothesis is:

Hypothesis 1: Firm size is positively/ negatively related to the cash holdings of the firms.

\subsubsection{Leverage}

Leverage is considered as an alternative to holding cash, and cash equivalents. Acharya, Almeida and Campello (2007) and Chen et al. (2015) identify that there is a negative relationship between leverage, and cash holdings. All major theories predict the same, as leverage reduces the danger of underinvestment, and imposes incremental external monitoring on the management. So, in light of these findings, the next hypothesis is:

Hypothesis 2: Leverage of the Firm Negatively Influences Cash Holdings

\subsubsection{Dividend}

Dividend payment reduce the cash reserves of the firm. Julio and Yook (2012), and Khieu and Pyles (2012), identify that dividends have a negative influence on the cash reserves of the firms. Nevertheless, Hill, Fuller, Kelly and Washam (2014) and, Chen, Chen, Schipper, Xu and Xue J (2012), find that there is a positive relationship between dividends, and cash holdings. The Shareholder Power Hypothesis also asserts that the dividends influence cash reserves positively. On the basis of these revelations, the next hypothesis is that: 
Hypothesis 3: Dividends have a positive/negative influence on cash holdings

\subsubsection{Financial Distress}

As per Subramaniam, Tang, Yue and Zhou (2011), financial distress has a positive effect on cash reserves, whereas, Khieu and Pyles (2012), and Lins et al. (2010) find that financial distress is negatively related with cash reserves, as firms facing severe insolvency cannot stockpile liquid assets. Hence, the next hypothesis is:

Hypothesis 4: There is a significant positive/ negative influence of financial distress on cash holdings.

\subsubsection{Growth Opportunities}

Asymmetry problems that firms come face to face with, usually intensify with an increase in growth options, which then cause an increase in the cost of external financing. In such situation, the liquid assets of a firm act as an insurance policy to high growth firms, and the probability of financial distress, and abandoning better investment opportunities is reduced (Iskandar-Datta \& Jia, 2014). Nevertheless, Bigelli and Vidal (2012), and Khieu and Pyles (2012), reveal that in mature and private firms, the options for growth do not increase cash reserves of the firms. Furthermore, firms may face a decline in cash reserves after financing the growth investments. From these revelations, the next hypothesis formulated is:

Hypothesis 5: Growth opportunities have a positive/negative influence on cash reserves

\subsubsection{Investment activities}

Typically, The Increase in investments reduce the cash reserves of the firms. This phenomenon is observed by Hoberg, Phillips and Prabhala (2014), for capital expenditures, and by Oler and Picconi (2014) for expenditures that were concerned with firm acquisitions. Opler et al. (1999) dentify that the capital expenditures influence the cash holdings of the firms in a positive way. From the above information gathered, the following hypothesis may be developed: 
Hypothesis 6: There is a significant positive/ negative impact of investments on the cash holdings of the firms.

\subsubsection{Cash Flows}

D'Mello, Krishnaswami and Larkin. (2008), have identified that there happens to be a significant positive impact of cash flows on the cash reserves of the firms. The Free Cash Flows (FCF) hypothesis and Pecking Order Theory also advocates the same beliefs. Hence, according to these research findings, the next hypothesis is:

Hypothesis 7: Cash flows have a positive influence on the cash holdings of the firms

\subsubsection{Profitability}

As per the Pecking Order Theory, cash reserves are stockpiled and built as a result of the investment decisions of the management, and the relevant financing necessary to raise capital. The Profitability of firms enhances their ability to make dividend payments, fulfill debt obligations, and hoard cash. Al Najjar and Clark (2017) also recognize the positive effects of profitability, on cash holdings. Therefore, as per Pecking Order Theory, and the empirical studies, the next hypothesis devised is:

Hypothesis 8: Profitability has a positive influence on the cash holdings of the firms.

\subsubsection{Net Working Capital}

One of the alternatives of cash holdings, in order to maintain liquidity in the firm, is the maintenance of net working capital. As per the Trade-off Theory, and studies conducted by Subramaniam et al. (2011) and Liu et al. (2014), net working capital, and cash holdings carry a negative relationship with each other. Hence, it may be hypothesized that:

Hypothesis 9: The net working capital has a negative influence on cash holdings.

\subsubsection{Institutional Factors Influencing Cash Holdings}

Pinkowitz et al. (2015) state that the firms hold lesser cash reserves as formal institutions move towards improved operations, simply for the reason that the agency problems are now better controlled, and managed 
in such institutions. If these intuitions are unable to protect the rights of the minority shareholders, and poor governance prevails in the country, the controlling managers or majority shareholders will be more tempted to use the cash reserves for their private benefits. On the other hand, however, the Shareholder Power Hypothesis predicts the opposite, and allows managers to hoard more money once the rights of the shareholders have been protected. The following are the formal institutions which are considered in this study, in order to analyze their effect on cash holdings:

\subsubsection{Shareholders' Right}

Dittmar et al. (2003) find that the shareholder's right leaves a negative impact on the cash holdings of firms. To them, the firms operating in countries which exercise poor shareholder rights, tend to stockpile more cash because the laws in such countries do not protect the rights of the shareholders, and as a result, the entrenched managers can accumulate higher cash reserves for their private benefits. In countries where there are strong shareholder rights, the situation flips to the opposite side, where the shareholders can force the managers of the firms to disgorge the cash holdings. The Outcome theory also advocates a negative relationship between the shareholder right, and cash holdings (La Porta, Lopez-deSilanes, Shleifer \& Vishny, 1999)

On the other hand, the Shareholder Power Hypothesis states that, the shareholders in the countries with high protected rights are less concerned with the cash that is stockpiled by the managers, and thus allow the managers to hoard money. By this logic, it may be hypothesized that:

Hypothesis 10: Shareholder rights protection is negatively/ positively associated with cash holdings

\subsubsection{Country Governance}

According to the Agency Theory, firms with more agency problems tend to have more cash holdings. Kusnadi, Y. (2011) identify that firms with weak governance are inclined towards hoarding more money, as compared to the firms with a strong governance in practice. Pinkowitz et al. (2015) argue that the cash holdings of the firms in countries which practice good governance, are lesser than firms in the countries which practice weak governance. Thus, we hypothesize that: 
Hypothesis 11: Country governance is negatively associated with cash holdings

\subsubsection{Financial Market Developments}

Also, the development of financial markets has an effect on the decision to hold cash reserves (Fan, Wong, \& Zhang, 2007). According to Caprio, Faccio and McConnell (2010), there is less friction, and expropriation by government officials, in the countries which have more developed markets, and as a result, the firms in such countries may hold more cash. On the other hand, in a developed market, the access to capital markets is easy, and the firms may intend to keep a lower level of cash due to the opportunity costs associated with cash holdings (Kusnadi, Yang \& Zhou, 2015). For this reason, we may hypothesize that:

Hypothesis 12: The development of the financial market is positively/ negatively associated with cash holdings

\subsection{Empirical Specification}

The general specification of the model is as under:

$$
\begin{aligned}
& C H_{i t}=\beta 0+\beta_{1} S_{R I}+\beta_{2} W_{i t}+\beta_{3} \text { MktCap }_{i t}+\beta_{4} \text { DomCrdt }_{i t}+\beta_{5} \text { SIZE }_{i t}+ \\
& \beta_{6} L E V_{i t}+\beta_{7} D I V_{i t}+\beta_{8} \text { Zscore }_{i t}+\beta_{9} I N V S T_{i t}+\beta_{10} I N T A N G_{i t}+\beta_{11} C F_{i t}+ \\
& \beta_{12} R O A_{i t}+\beta_{13} N W C_{i t}+\varepsilon_{i t}
\end{aligned}
$$

Where $\mathrm{CH}$ is cash, and cash equivalents, divided by the total assets ratio; SRI is the Anti-Director Index (ADRI) from Porta, Lopez-de-Silanes, Shleifer and Vishny (1998), as revised in Djankov (2009), which is used as a proxy of the Shareholder right index; WGI is the overall governance of a country; MktCap is the market capitalization of the listed domestic companies, and DomCrdt is the domestic credit that is provided by the financial sector- both are proxies that are used for financial developments; Size is the natural logarithm of total assets; LEV is the total debt to total assets; DIV is the ratio of total dividends to total assets; Zscore is Altman's z-score, which is a proxy used for financial distress; INVST is measured as the capital expenditure to total assets; INTANG denotes the intangible assets to total assets; CF represents the operational cash flows divided by total assets; ROA is the ratio of net income to total assets; NWC is the net working capital, divided by total assets; and finally, $\varepsilon$ is the error term. Table A1 presents the calculations for all the relevant variables. 


\section{Table A1: Description of Variables}

\begin{tabular}{|c|c|c|}
\hline Symbols & Variables & Description \\
\hline SRI & Shareholder right index & $\begin{array}{l}\text { Anti-director index (ADRI) from La } \\
\text { Porta et. al (1998) as revised in Djankov } \\
\text { et al. (2009) }\end{array}$ \\
\hline WGI & Worldwide governance index & $\begin{array}{l}\text { Worldwide Governance Indicators } \\
\text { (WGI) from World Bank database. }\end{array}$ \\
\hline Mktcap & Market Capitalization & Market Capitalization divided by GDP \\
\hline Domcrdt & $\begin{array}{l}\text { Domestic credit provided by } \\
\text { banks }\end{array}$ & $\begin{array}{l}\text { Domestic credit provided by banks } \\
\text { divided by GDP }\end{array}$ \\
\hline Z SCORE & $\begin{array}{l}\text { Financial Risk/ Financial } \\
\text { strength }\end{array}$ & Altman's Z- Score \\
\hline INVST & Capital Expenditure & Capital expenditure/Total assets \\
\hline INTAN & Intangibles & Intangibles/ Sales \\
\hline $\mathrm{CF}$ & Cash flows & Operational cash flows / Total assets \\
\hline $\mathrm{ROA}$ & Profitability & Net Profit/ Total assets \\
\hline NWC & Net Working Capital & Net Working Capital / Total assets \\
\hline
\end{tabular}

Note: This table provides definitions of cash holdings and independent variables including shareholder right index, worldwide governance index, and market capitalization as percentage of GDP, domestic credit provided by bank divided by GDP and firm specific variables for cash reserves.

For the purpose of estimating the model with the best approach, there is need to understand the objective of the study. In our sample data, we have made use of firm specific variables which are time variant, and are unique to each firm. Furthermore, there are country specific variables as well, out of which the shareholder right index (SRI) is time invariant, with one value available for each country, whereas, the Worldwide Governance Index (WGI), Equity Market Capitalization and Domestic Bank Credit are time variant, which means that their values change over a certain period of time for a country, but for each firm of the country, the values will remain the same. Hence, the panel data is used to estimate the model, by applying GLS along with the cross section weights. It must also be noted that, heteroskedasticity poses as a challenge which may be encountered in the panel data analysis, and as a repercussion, the results might come out to be inconsistent. So, in order to curb this problem, this study uses the PCSE correction method to control for heteroskedasticity. 


\subsection{Sample and Data}

This study analyzes data pertaining to two main regions of the world, including Europe and Asia Pacific. The sample consists of 4,662 firms, extracted from the World Scope database. From Europe, 3,358 firms, and from Asia Pacific, 1,304 firms are selected for the purpose of this study, which focuses on the findings between the periods of 2007 to 2016. The firms are selected on the basis of the availability of financial data in the World Scope database. The detail is placed at Table A2, in the appendix.

Table A2: Regions, Countries and Number of Observations

\begin{tabular}{lclc}
\hline \multicolumn{2}{c}{ AISA PACIFIC } & \multicolumn{2}{c}{ EUROPE } \\
\hline Country & Observations & Country & Observations \\
\hline Australia & 2,220 & Austria & 100 \\
China & 570 & Belgium & 320 \\
Hong Kong & 3,660 & Czech Republic & 30 \\
India & 3,040 & Denmark & 450 \\
Indonesia & 440 & Finland & 540 \\
Japan & 5,910 & France & 1,200 \\
Malaysia & 5,610 & Germany & 1,800 \\
Newzeland & 2,650 & Greece & 610 \\
Pakistan & 120 & Hungry & 40 \\
Peru & 490 & Ireland & 180 \\
Philippine & 100 & Italy & 710 \\
Singapore & 520 & Netherland & 490 \\
South Korea & 1,510 & Norway & 270 \\
Taiwan & 1,550 & Poland & 320 \\
Thailand & 5,190 & Portugal & 150 \\
& & Spain & 340 \\
& & Sweden & 690 \\
& & Switzerland & 820 \\
& & Turkey & 620 \\
& & United Kingdom & 3,360 \\
& 33,580 & & $\mathbf{1 3 , 0 4 0}$ \\
\hline
\end{tabular}

Note: This table provides detail of name of countries, regions and number of observation. For each region, total number of observations is presented. For Europe sample, total number of observations is 13,040 and for Asia Pacific sample is 33,580.

For formal institutions, we obtained the data from a variety of sources. We obtained data from the Worldwide Governance Indicators (WGI), extracted from the World Bank database. Following the research of Kaufmann, Kraay, and Mastruzzi (2009), and Pinkowitz et al. (2015), we 
used an average of the six indicators, as a proxy of the overall governance of a country. Furthermore, we used the Anti-Director Index as a proxy of the Shareholder Right Index (SRI).For financial developments, the Stock Market Capitalization, and the Domestic Credit provided by banks are used as proxies. The data on Stock Market Capitalization, and the Domestic Credit by banks are obtained from the World Bank.

\section{Empirical Results}

At the first, summary statistics is provided and then regression results of panel data are presented for both regions separately.

\subsection{Summary Statistics}

The descriptive statistics for the firm specific variables, and formal institutions for Europe and Asia pacific regions are presented at table A3. The table shows the maximum, and the minimum values for different, firm specific, variables and formal institutions with respect to Europe and Asia Pacific. The maximum and minimum values of the cash holdings are $53 \%$ and $1 \%$, respectively, for European firms, and, $58 \%$ and $2 \%$, respectively, for Asian Pacific firms. Similarly, the maximum and minimum values for other cash holding determinants are presented in the said table.

The table further depicts that cash holdings have a median value of $9.49 \%$ in Europe, which is lower than a median value of $11.22 \%$, for Asia Pacific, depicting that companies in the Asia Pacific region have more cash holdings than that of Europe. A comparison of the formal institutions between Europe and Asia Pacific reveals that the median values of SRI, WGI, stock market capitalization and domestic credit provided by banks are 3.50, 87.79, 61.20and, 156.01, respectively, for Europe, and 4.5, 72.87, 82.84 and 151.04 respectively for Asia Pacific. Median values of SRI, and stock market capitalization for Europe, are lower than those on Asia Pacific, which means that the shareholder rights are more and better protected in Asia Pacific countries, than in Europe. The median value of WGI, and the domestic credit provided by banks are higher than that of Asia Pacific which shows that the overall country governance, and credit markets in Europe are better than those in Asia Pacific. 


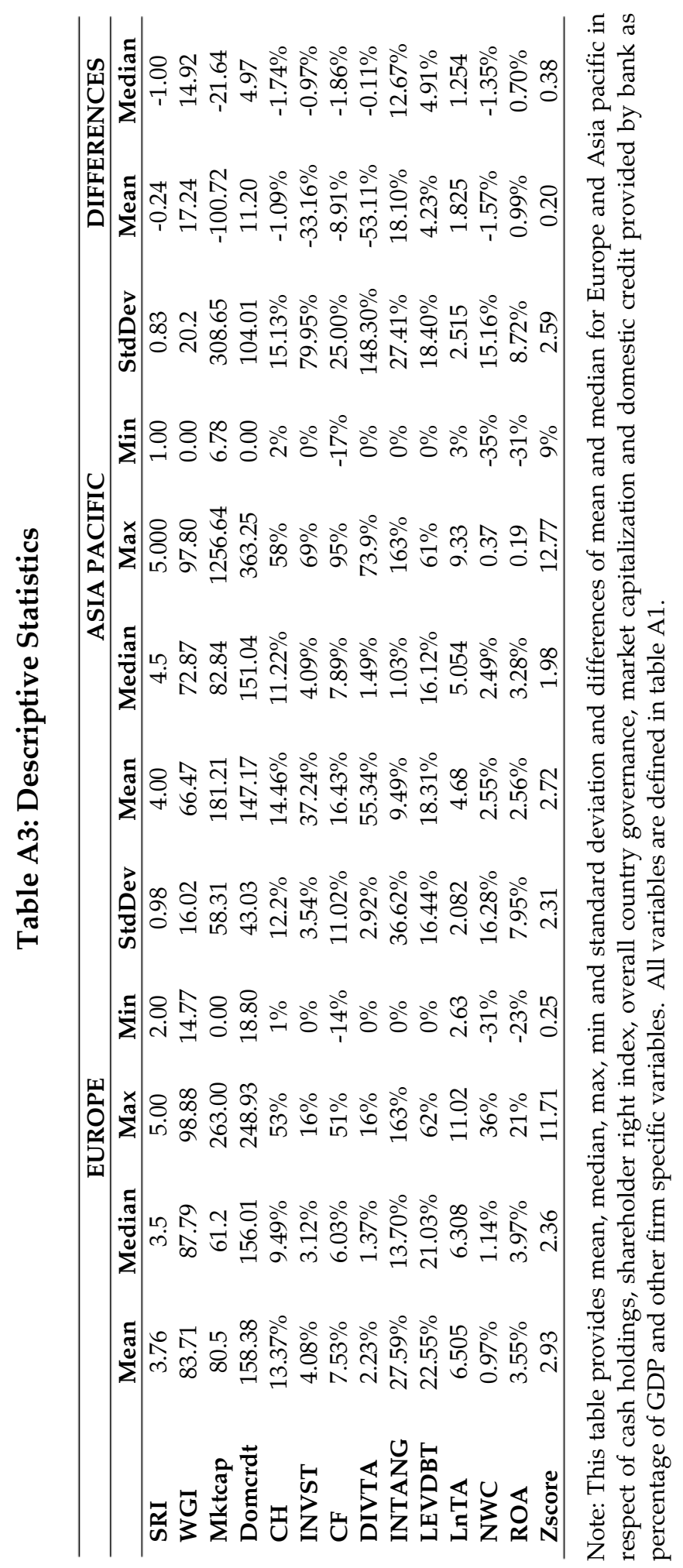




\subsection{Regression Results of Formal Institutions and Firm Specific Determinants}

Table A4 contains the results of our study, specifically pertaining to the cash holding determinants in Europe. Although, the base equation is 3.1 , in order to analyze the impact of formal institutions on cash reserves, bit by bit, there were four regressions (i) to (iv) that were run for Europe, as shown in table A4. Regression (iv) of table A4 estimates the equation 3.1.

\section{Table A4: Europe Regression analysis predicting influence of formal institutions and firm specific variables on cash holdings}

\begin{tabular}{|c|c|c|c|c|}
\hline Variables & (i) & (ii) & (iii) & (iv) \\
\hline SRI & $\begin{array}{l}0.00^{* * *} \\
(46.11)\end{array}$ & $\begin{array}{l}0.00^{* * *} \\
(10.02)\end{array}$ & $\begin{array}{l}0.00^{* * *} \\
(-2.45)\end{array}$ & $\begin{array}{c}-0.006^{\text {*** }} \\
(-9.980)\end{array}$ \\
\hline WGI & & $\begin{array}{c}-0.001^{* * *} \\
(-22.07)\end{array}$ & $\begin{array}{c}-0.001^{* * *} \\
(-23.41)\end{array}$ & $\begin{array}{l}-0.001^{* * *} \\
(-29.020)\end{array}$ \\
\hline МКТСАР & & & $\begin{array}{c}0.0002^{* * *} \\
(15.20)\end{array}$ & $\begin{array}{c}0.0001^{* * *} \\
(10.880)\end{array}$ \\
\hline DOMCRDT & & & $\begin{array}{c}0.00003 \\
(0.93)\end{array}$ & $\begin{array}{c}0.0001^{* * *} \\
(5.085)\end{array}$ \\
\hline LNTA & & & & $\begin{array}{c}-0.002^{* * * *} \\
(-6.784)\end{array}$ \\
\hline LEVDBT & & & & $\begin{array}{l}-0.109^{* * * *} \\
(-30.232)\end{array}$ \\
\hline DIVTA & & & & $\begin{array}{c}-0.176^{* * *} \\
(-7.629)\end{array}$ \\
\hline ZSCORE & & & & $\begin{array}{l}0.020^{* * *} \\
(45.670)\end{array}$ \\
\hline INVST & & & & $\begin{array}{l}-0.362^{* * * *} \\
(-24.096)\end{array}$ \\
\hline INTANG & & & & $\begin{array}{l}-0.052^{* * *} \\
(-39.014)\end{array}$ \\
\hline CF & & & & $\begin{array}{c}0.038^{* * * *} \\
(7.246)\end{array}$ \\
\hline ROA & & & & $\begin{array}{c}-0.098^{* * * *} \\
(-9.658)\end{array}$ \\
\hline NWC & & & & $\begin{array}{l}-0.243^{* * * *} \\
(-69.017)\end{array}$ \\
\hline $\mathrm{C}$ & $\begin{array}{l}0.11^{\text {*** }} \\
(55.69)\end{array}$ & $\begin{array}{l}0.18^{* * *} \\
(55.69)\end{array}$ & $\begin{array}{l}0.19^{* * *} \\
(51.06)\end{array}$ & $\begin{array}{l}0.23^{* * *} \\
(54.75)\end{array}$ \\
\hline R-square & $\begin{array}{l}0.00 \\
1304\end{array}$ & $\begin{array}{l}0.04 \\
1304\end{array}$ & $\begin{array}{l}0.06 \\
1304\end{array}$ & $\begin{array}{l}0.49 \\
1304\end{array}$ \\
\hline
\end{tabular}

Note: This table presents regression results of formal institutions and firm specific variables on cash holdings in respect of Europe. The period of study is 2007-2016. There are 13,040 firm-years from 20 European countries. All variables are defined in table A1. In column (i) to (iv), EGLS (PCSE), regression results of different models are reported. Winsorization of variables is made at the $5 \%$ level. In parentheses, robust $\mathrm{t}$-statistics are reported. ${ }^{*} \mathrm{P}<0.10$; ${ }^{* *} \mathrm{P}<0.05$; ${ }^{* * *} \mathrm{P}<0.01$ 
In Model (i) of table A4, only SRI is taken as the explanatory variable, and the cash holdings are taken as the dependent variable. Contrary to the study of Dittmar et al. (2003), and the Tradeoff Theory, the SRI is positive and significant, but the adjusted R square is only $0.07 \%$. In the regression (ii), we add WGI, in order to analyze its effect on cash holdings, along with the SRI. The negative coefficient of WGI is negative, which indicates that an improvement in country governance reduces the need to hoard cash. The SRI is still positive in model (ii). However, the adjusted R square is only $2 \%$, which casts doubts on the validity of the said two variables, especially in terms of explaining the variation in the cash holdings in Europe.

In regression (iii), we add proxies of financial development, including stock market capitalization and domestic credit by banks as a percentage of the GDP. The results show that the credit market development, and the stock market development have a positive impact on the cash holdings, which in turn indicates that when it is easier to hoard cash, companies hold cash which is supportive of the teachings of the Agency Theory. This interpretation is of course partially supported because of the insignificance of the credit market development. The economic significance of the model, however, does not increase visibly, and the adjusted $\mathrm{R}$ square could be increased to only $3 \%$ in regression (iii).

Finally, firm specific variables were added to the formal institutions in regression (iv). In this model, the SRI turns to negative, which is in accordance with the Agency Theory, and the researches of Ferreira and Vilela (2004), and Akguc and Choi (2013). The negative sign of shareholder right is indicative of agency problems in European firms.

Results reveal that WGI have a negative influence on cash holdings, which shows that thr shareholders of the countries with a strong country governance have the power to force the managers of the firms to reduce cash holdings. Both the proxies of financial markets' development are positively significant, which shows that firms with strongly developed markets can hoard more cash.

The results of the regression (iv) in table A4, for firm specific factors, state that the size influences the cash reserves negatively. This corresponds to the studies of Qiu and Wan (2015) and Lins et al. (2010), and also in accordance with Trade-off Theory. 
Furthermore, this study identifies that leverage has a negative influence on cash holdings. This is in line with the studies of Al- Najjar (2013), Akguc and Choi (2013), Guizani (2017) and, Chen Li, Xiao and Zou (2014). Thus, the results reveal that, firms with lower leverage have easy access to external financing which they eventually use to fund their investments, and so have to be less dependent on cash holdings. This finding for European companies supports our hypothesis $\mathrm{H} 2$.

The results indicate that dividend payments negatively influence cash holdings for European firms. This corresponds to the researches of Khieu and Pyles (2012), and Al-Najjar (2013), and hypothesis H3.

For the companies in Europe, results reveal that the z-score has a positive impact on cash holdings. Subramaniam et al. (2011) and Harford, Mansi and Maxwell (2008) also indicate the same findings in their studies. The results of this study also confirm the validity of the hypothesis, $\mathrm{H} 4$, which claims that financial distress has a positive/ negative influence cash reserves of the firms.

The results indicated in Table A4 indicate that there is a negative effect of intangibles on cash holdings. Intangibles are used as a proxy of firm's growth. Bigelli and Vidal (2012), and Khieu and Pyles (2012) also find the same revelations in their studies. However, Iskandar-Datta et al. (2014), Foley et al. (2007) and Chen et al. (2015) identify a positive association between growth and cash reserves. This result also confirms our hypothesis, H5, which states that there is a significant positive/ negative impact of growth on cash reserves.

The results stated in table A4 further reveal that there is a positive impact of investments on cash reserves of the European firms. Dittmar et al. (2003) and Hoberg et al. (2014) also find that both the variables have a positive relationship with each other. The results of the study also confirm the hypothesis $\mathrm{H6}$, which states that investments have a positive/ negative effect on cash holdings.

Further on in the study, the research reveals that cash flows have a positive influence on cash reserves of the European firms. Free Cash flow Hypothesis and the Pecking Order Theory also postulate the same relationship. Other studies also validate the same relationship between the said variables (D'Mello et al., 2008; Kalcheva \& Lins, 2007; Weidemann, 2016). This also confirms the hypothesis H7. The results stated in table A4 further reveal that profitability carries a negative association with cash 
holdings. This finding, however, shows a contrast to the studies of Ferreira and Vilela (2004), and Al-Najjar and Belghitar (2011), who identify the positive effect of profitability, on cash holdings.

It is also evident from table A4 that, for European firms, the net working capital influences cash holdings in a negative manner. The same results are identified by Al-Najjar (2013) and Liu et al. (2014). Moreover, these results also correspond to hypothesis, H9 and the Tradeoff Theory.

In table A5, the results for Asia Pacific are presented at regression (i) to (iv). Through regressions (i) to (iv), the SRI is positive. The Shareholder Power Hypothesis supports this positive relationship. This means that the shareholders in the country with a strong shareholder right may allow the managers of the firms to hoard cash, due to the reason that there prevails more social trust in their respective country (Dudley \& Zhang, 2016). Also, the substitute hypothesis states that the shareholders are less concerned with the additional cash holdings that are held by the managers.

The value of WGI is also positive, and significant in regression (ii) and (iii) that is presented in table A5. Furthermore, it is also positive in regression (iv), but that value is insignificant. The positive relationship between WGI, and cash holdings is explained by Kalcheva and Lins (2007). To them, in countries with strong governance, shareholders are less concerned with the cash holding tendency of the managers. Pinkowitz et al. (2015) also find that WGI has a positive impact on cash holdings, specifically for US and other foreign companies, though this relationship is insignificant. Also, Najjar and Basil (2015) find that there is an insignificant relationship between governance and cash holdings for SMEs in the UK.

Both proxies of the financial market developments are negative in regression (iii) and (iv), as seen in table A5. This is in line with the Shareholder Power Hypothesis, and contradictory to the Agency View for cash holdings. 
Table A5: Asia Pacific Regression Analysis Predicting Influence of Formal Institutions and Firm Specific Variables on Cash Holdings

\begin{tabular}{|c|c|c|c|c|}
\hline Variables & (i) & (ii) & (iii) & (iv) \\
\hline SRI & $\begin{array}{l}0.01^{* * *} \\
(13.07)\end{array}$ & $\begin{array}{l}0.01^{* * *} \\
(9.60)\end{array}$ & $\begin{array}{l}0.01^{* * *} \\
(12.57)\end{array}$ & $\begin{array}{c}0.006^{* * *} \\
(5.727)\end{array}$ \\
\hline WGI & & $\begin{array}{c}0.0001^{*} \\
(2.20)\end{array}$ & $\begin{array}{c}0.0003^{* * *} \\
(5.39)\end{array}$ & $\begin{array}{c}0.0001 \\
(-0.231)\end{array}$ \\
\hline МКТСАР & & & $\begin{array}{c}0.00003^{* * *} \\
(-11.06)\end{array}$ & $\begin{array}{r}0.00001^{* *} \\
(-2.807)\end{array}$ \\
\hline DOMCRDT & & & $\begin{array}{c}0.00003^{* * *} \\
(-3.33)\end{array}$ & $\begin{array}{c}0.00002^{* *} \\
(-2.655)\end{array}$ \\
\hline LNTA & & & & $\begin{array}{l}0.010^{* * *} \\
(29.401)\end{array}$ \\
\hline LEVDBT & & & & $\begin{array}{l}-0.174^{* * *} \\
(-43.898)\end{array}$ \\
\hline DIVTA & & & & $\begin{array}{c}-0.004^{* * *} \\
(-7.185)\end{array}$ \\
\hline ZSCORE & & & & $\begin{array}{l}0.021^{* * *} \\
(74.483)\end{array}$ \\
\hline INVST & & & & $\begin{array}{l}0.017^{* * *} \\
(22.427)\end{array}$ \\
\hline INTANG & & & & $\begin{array}{c}-0.019^{* * * *} \\
(-8.367)\end{array}$ \\
\hline CF & & & & $\begin{array}{l}0.035^{* * *} \\
(10.901)\end{array}$ \\
\hline ROA & & & & $\begin{array}{l}-0.220^{* * *} \\
(-26.780)\end{array}$ \\
\hline NWC & & & & $\begin{array}{l}-0.102^{* * *} \\
(-24.698) \\
\end{array}$ \\
\hline C & $\begin{array}{l}0.09^{* * *} \\
(27.51)\end{array}$ & $\begin{array}{l}0.09^{* * *} \\
(26.77)\end{array}$ & $\begin{array}{l}0.07^{* * *} \\
(16.97)\end{array}$ & $\begin{array}{l}0.05^{* * *} \\
(10.88)\end{array}$ \\
\hline $\begin{array}{l}\text { R-square } \\
\text { obs }\end{array}$ & $\begin{array}{l}0.00 \\
3358\end{array}$ & $\begin{array}{l}0.01 \\
3358\end{array}$ & $\begin{array}{l}0.01 \\
3358\end{array}$ & $\begin{array}{c}0.28 \\
3358\end{array}$ \\
\hline
\end{tabular}

Note: This table presents regression results of formal institutions and firm specific variables on cash holdings in respect of Asia Pacific. The period of study is 2007-2016. There are 33,580 firm-years from 15 Asia Pacific countries. All variables are defined in table A1. In column (i) to (iv), EGLS (PCSE), regression results of different models are reported. Winsorization of variables is made at the $5 \%$ level.. In parentheses, robust $\mathrm{t}$-statistics are reported. ${ }^{*} \mathrm{P}<0.10 ;{ }^{* *} \mathrm{P}<0.05 ;{ }^{* * *} \mathrm{P}<0.01$

It is important to mention that the coefficient value of WGI, stock market capitalization and domestic credit provided by the banks are very trivial in terms of value. These trifling coefficients values show that WGI, and the financial development variables have an invisible effect on cash 
holdings for Asia Pacific, though these are statistically significant for the financial market development.

In regression (iv), the effect of different firm specific factors on cash holdings is also shown for Asia Pacific. The results reveal that leverage, dividend, intangibles, net working capital and profitability are negatively associated with cash holdings, whereas the z-score and cash holdings have a positive influence on cash holdings in the Asia Pacific region. It must be noted that these results are coherent with the results of Europe. The effects of size and investments, on cash holdings for Asia Pacific, are contradictory to those of Europe. In Asia Pacific, the size of the firm has a significant positive effect on cash holdings. A positive, significant relationship between size, and cash holdings, in the case of Asia Pacific, corresponds with the studies of Ozkan and Ozkan (2004) and, Liu, Luo and Tian (2015), and the Shareholders' Protection Hypothesis.

Similarly, investments influence cash holdings positively for firms in the Asia Pacific region, which happens to be different from Europe, where the relationship between the said variables is negative. The same, positive relationship between capital expenditures and cash holdings is investigated by Harford, Mansi, and Maxwell (2008) and, Huang and Kisgen (2013).

To sum up, formal institutions including SRI, WGI, and the financial market developments of Asia Pacific, and Europe are different from each other, due to which there is evidence of varying effects on cash holding decisions. The SRI in Europe has a negative effect on the cash reserves, whereas in Asia Pacific, this relationship is positive. The negative relationship between SRI, and cash holding is as per the Agency Theory, and a positive relationship in Asia Pacific is supported by the Shareholder Power Hypothesis. From the results of the study, it may be deduced that shareholders in Asia Pacific have more trust in the managers of their firms, as compared to those in Europe.

The same explanation is valid for the impact of worldwide governance on cash holdings for Europe and Asia pacific. The negative influence of WGI on cash holdings in Europe indicates that the shareholders of the firms operating in European countries, with good governance, do not trust the managers of their firms due to agency concerns, and may force them to disgorge the cash level. On the other hand, in Asia Pacific, a positive relationship between WGI, and cash holdings, show that the shareholders of the firms in the countries specific to Asia 
Pacific, allow managers of the firms to hoard more cash, when the overall governance of the country is good. In Asia Pacific, however, the effect of WGI, on cash holdings is insignificant, especially when the formal institutions are combined with the firm specific factors.

Similarly, a positive relationship between the financial market development, and cash holdings in Europe, is an indication of agency motives, whereas there is a negative effect of the financial market development, on the cash holdings in Asia Pacific, which supports the argument in favor of the Shareholder Power Hypothesis. As far as the effect of the firm specific variables, on cash holdings in Asia Pacific and Europe is concerned, we find similarities in both the regions for most of the factors. The difference of effect in both the regions is found mainly in their size and investments.

\subsection{Robustness of Multiple Analysis}

In this sub-section, different tests are applied in order to check the robustness of our findings that are presented in tables A4, and A5. The robustness of the findings is tested by making changes in the time period, and the estimation techniques applied to the variables and determinants in question.

\subsubsection{Regression with Different Time Periods}

One way to verify the robustness of the results that are presented in table A4\& A5, is to divide the total periods into two parts, and then run the model separately for each period. We divide our sample period of ten years into two sub-samples i.e. one period from 2007 to 2011, and the other from 2012 to 2016.The regression is run for both periods with respect to Europe and Asia Pacific. The results of the period wise regressions are presented in tables A6 and A7, for Europe and Asia Pacific, respectively.

It is revealed from columns (2) and (3) of the table A6, that the results for Europe are the same as those that were extracted from our basic regressions that are presented in table A4. Only one change is observed, which pertains to the credit market development for the period of 2006 to 2011, i.e. it turns to insignificant. Furthermore, it is shown in column (2) and (3) of table A7, that for the Asia Pacific region, the regression results are the same as they are in the basic regression that was run and presented in table A5. 
Table A6: Europe Regression analysis predicting influence of formal institutions and firm specific variables on cash holdings

\begin{tabular}{|c|c|c|c|c|c|}
\hline Variables & EGLS (PCSE) & EGLS (PCSE) & EGLS (PCSE) & GMM & WLS \\
\hline & 2007-2016 & 2007-2011 & 2012-2016 & 2007-2016 & 2007-2016 \\
\hline \multirow[t]{2}{*}{ SRI } & $-0.006^{* * *}$ & $-0.004^{* * *}$ & $-0.006^{* * *}$ & $-0.007^{* * *}$ & $-0.006^{* * *}$ \\
\hline & $(-9.980)$ & $(-5.289)$ & $(-10.411)$ & $(-5.537)$ & $(-5.163)$ \\
\hline \multirow[t]{2}{*}{ WGI } & $-0.001^{* * *}$ & $-0.001^{* * *}$ & $-0.001^{* * *}$ & $-0.001^{* * *}$ & $-0.001^{* * *}$ \\
\hline & $(-29.020)$ & $(-22.965)$ & $(-27.628)$ & $(-19.184)$ & $(-19.118)$ \\
\hline \multirow[t]{2}{*}{ MKTCAP } & $0.0001^{* * *}$ & $0.0001^{* * *}$ & $0.0001^{* * *}$ & $0.0001^{* * *}$ & $0.0001^{* * *}$ \\
\hline & $(10.880)$ & $(4.446)$ & $(18.517)$ & $(4.628)$ & $(6.236)$ \\
\hline \multirow[t]{2}{*}{ DOMCRDT } & $0.00001^{* * *}$ & 0.00001 & $0.00001^{* * *}$ & $0.00001^{* *}$ & $0.00001^{* *}$ \\
\hline & $(5.085)$ & $(0.930)$ & (9.357) & (3.247) & $(3.136)$ \\
\hline \multirow[t]{2}{*}{ LNTA } & $-0.002^{* * *}$ & $-0.002^{* * *}$ & $-0.001^{* * *}$ & $-0.002^{* * *}$ & $-0.003^{* * *}$ \\
\hline & $(-6.784)$ & $(-7.023)$ & $(-4.779)$ & $(-3.561)$ & $(-6.484)$ \\
\hline \multirow[t]{2}{*}{ LEVDBT } & $-0.109^{* * *}$ & $-0.123^{* * *}$ & $-0.115^{* * *}$ & $-0.151^{* * *}$ & $-0.128^{* * *}$ \\
\hline & $(-30.232)$ & $(-26.693)$ & $(-26.732)$ & $(-17.832)$ & $(-19.556)$ \\
\hline \multirow[t]{2}{*}{ DIVTA } & $-0.176^{* * *}$ & $-0.198^{* * *}$ & $-0.161^{* * *}$ & $-0.368^{* * *}$ & $-0.136^{* * *}$ \\
\hline & $(-7.629)$ & $(-6.848)$ & $(-5.607)$ & $(-4.685)$ & $(-3.535)$ \\
\hline \multirow[t]{2}{*}{ ZSCORE } & $0.020^{* * *}$ & $0.021^{* * *}$ & $0.019^{* * *}$ & $0.019^{* * *}$ & $0.021^{* * *}$ \\
\hline & $(45.670)$ & $(36.654)$ & $(34.688)$ & (16.638) & $(37.703)$ \\
\hline \multirow[t]{2}{*}{ INVST } & $-0.362^{* * *}$ & $-0.397^{* * *}$ & $-0.306^{* * *}$ & $-0.448^{* * *}$ & $-0.367^{* * *}$ \\
\hline & $(-24.096)$ & $(-21.932)$ & $(-17.168)$ & $(-11.022)$ & $(-13.662)$ \\
\hline \multirow[t]{2}{*}{ INTANG } & $-0.052^{* * *}$ & $-0.048^{* * *}$ & $-0.053^{* * *}$ & $-0.061^{* * *}$ & $-0.054^{* * *}$ \\
\hline & $(-39.014)$ & $(-29.977)$ & $(-37.026)$ & $(-19.383)$ & $(-20.436)$ \\
\hline \multirow[t]{2}{*}{$\mathrm{CF}$} & $0.038^{* * *}$ & $0.036^{* * *}$ & $0.032^{* * *}$ & $0.022^{* *}$ & $0.023^{* *}$ \\
\hline & $(7.246)$ & $(4.690)$ & $(5.863)$ & $(2.352)$ & $(2.621)$ \\
\hline \multirow[t]{2}{*}{ ROA } & $-0.098^{* * *}$ & $-0.127^{* * *}$ & $-0.116^{* * *}$ & $-0.191^{* * *}$ & $-0.159^{* * *}$ \\
\hline & $(-9.658)$ & $(-9.639)$ & $(-9.526)$ & $(-5.439)$ & $(-10.947)$ \\
\hline \multirow[t]{2}{*}{ NWC } & $-0.243^{* * *}$ & $-0.253^{* * *}$ & $-0.251^{* * *}$ & $-0.269^{* * *}$ & $-0.282^{* * *}$ \\
\hline & $(-69.017)$ & $(-55.352)$ & $(-59.696)$ & $(-32.423)$ & $(-46.056)$ \\
\hline \multirow[t]{2}{*}{ C } & $0.23^{* * *}$ & $0.246^{* * *}$ & $0.216^{* * *}$ & $0.26^{* * *}$ & $0.26^{* * *}$ \\
\hline & (54.75) & $(47.532)$ & $(44.022)$ & (33.14) & $(37.50)$ \\
\hline R-square & 0.49 & 0.584 & 0.582 & 0.29 & 0.30 \\
\hline Obs & 13,040 & 13,040 & 13,040 & 13,040 & 13,040 \\
\hline
\end{tabular}

Note: This table presents regression results of formal institutions and firm specific variables on cash holdings in respect of Europe for 13,040 observations from 20 countries. In column (1) of the table, regression results of EGLS (PCSE) are reported for the period 2007 to 2016 for reference purpose. In column (2), regression results of EGLS (PCSE) for the year 2007 to 2011 are stated. In column (3), regression results of EGLS (PCSE) for the year 2012 to 2016 are presented. Columns (4) and (5) report regression results of GMM and WLS methods respectively for the period 2007 to 2016. All variables are defined in table A1. Winsorization of variables is made at the $5 \%$ level. In parentheses, robust $\mathrm{t}$-statistics are reported. ${ }^{*} \mathrm{P}<0.10$; ** $\mathrm{P}<0.05$; *** $\mathrm{P}<0.01$.

\subsubsection{Regression with Instrument Variables}

One of the ways to deal with possible endogeneity among cash holdings, dividend, leverage and investments, is to apply the Instrumental 
Variable (IV) Estimator. A standard form of the models is a two-stage least squares (2SLS), but a generalized method of moment (GMM) estimators is also used (Amess, Banerji \& Lampousis, 2015). The results of the GMM for Europe and Asia pacific are presented in table A6 and A7, respectively.

In column (4) of table A6, the regression results of the Generalized Method of Moment (GMM) for Europe are presented. Interestingly, similar results are found in our base regression in table A4. The results of GMM regression are presented for Asia Pacific in column (4) of table A7.With some deviations, the results of this regression confirm our findings for basic regression, i.e. the generalized least square (GLS), in table A5.

\subsubsection{Robustness with WLS}

Following Pinkowitz et al. (2015), we apply the Weighted Least Square (WLS) method to confirm our findings in table A4, and A5 for Europe and Asia Pacific, respectively. The results of WLS for Europe are reported in column (5) of table A6, and for Asia Pacific, the results are presented in column (5), of tableA7. 


\section{Table A7: Asia Pacific Regression analysis predicting influence of formal institutions and firm specific variables on cash holdings}

\begin{tabular}{|c|c|c|c|c|c|}
\hline Variables & EGLS (PCSE) & EGLS (PCSE) & EGLS (PCSE) & GMM & WLS \\
\hline & 2007-2016 & 2007-2011 & 2012-2016 & 2007-2016 & 2007-2016 \\
\hline \multirow[t]{2}{*}{ SRI } & $0.006^{* * *}$ & $0.006^{* * *}$ & $0.005^{* * *}$ & $0.005^{* * *}$ & $0.005^{* * *}$ \\
\hline & $(5.727)$ & $(5.622)$ & (3.779) & $(3.478)$ & $(4.048)$ \\
\hline \multirow[t]{2}{*}{ WGI } & 0.00001 & 0.00001 & 0.00001 & 0.00001 & 0.00001 \\
\hline & $(-0.231)$ & $(0.0730$ & $(-0.739)$ & $(0.980)$ & $(0.743)$ \\
\hline \multirow[t]{2}{*}{ MKTCAP } & $0.00001^{* *}$ & $0.00001^{* * *}$ & 0.00001 & 0.00001 & 0.00001 \\
\hline & $(-2.807)$ & $(-3.284)$ & $(-1.189)$ & $(-0.897)$ & $(-1.546)$ \\
\hline \multirow[t]{2}{*}{ DOMCRDT } & $0.00002^{* *}$ & $0.00002^{* *}$ & $0.00002^{*}$ & $0.00002^{*}$ & $0.00002^{*}$ \\
\hline & $(-2.655)$ & $(-2.237)$ & $(-1.895)$ & $(-1.972)$ & $(-2.050)$ \\
\hline \multirow[t]{2}{*}{ LNTA } & $0.010^{* * *}$ & $0.010^{* * *}$ & $0.010^{* * *}$ & $0.009^{* * *}$ & $0.009^{* * *}$ \\
\hline & $(29.401)$ & $(24.794)$ & $(25.810)$ & (21.181) & $(22.017)$ \\
\hline \multirow[t]{2}{*}{ LEVDBT } & $-0.174^{* * *}$ & $-0.166^{* * *}$ & $-0.176^{* * *}$ & $-0.159^{* * *}$ & $-0.159^{* * *}$ \\
\hline & $(-43.898)$ & $(-35.836)$ & $(-38.270)$ & $(-31.08)$ & $(-32.55)$ \\
\hline \multirow[t]{2}{*}{ DIVTA } & $-0.004^{* * *}$ & $-0.004^{* * *}$ & $-0.003^{* * *}$ & $-0.002^{* * *}$ & $-0.003^{* * *}$ \\
\hline & $(-7.185)$ & $(-5.162)$ & $(-4.261)$ & $(-2.652)$ & $(-3.747)$ \\
\hline \multirow[t]{2}{*}{ ZSCORE } & $0.021^{* * *}$ & $0.021^{* * *}$ & $0.021^{* * *}$ & $0.021^{* * *}$ & $0.021^{* * *}$ \\
\hline & $(74.483)$ & $(61.847)$ & $(60.527)$ & (59.884) & $(62.589)$ \\
\hline \multirow[t]{2}{*}{ INVST } & $0.017^{* * *}$ & $0.015^{* * *}$ & $0.018^{* * *}$ & $0.018^{* * *}$ & $0.017^{* * *}$ \\
\hline & $(22.427)$ & $(17.467)$ & $(19.481)$ & $(16.037)$ & $(16.800)$ \\
\hline \multirow[t]{2}{*}{ INTANG } & $-0.019^{* * *}$ & $-0.019^{* * *}$ & $-0.015^{* * *}$ & $-0.017^{* * *}$ & $-0.017^{* * *}$ \\
\hline & $(-8.367)$ & $(-7.136)$ & $(-5.740)$ & $(-5.866)$ & $(-6.106)$ \\
\hline \multirow[t]{2}{*}{ CF } & $0.035^{* * *}$ & $0.032^{* * *}$ & $0.041^{* * *}$ & $0.023^{* * *}$ & $0.025^{* * *}$ \\
\hline & $(10.901)$ & $(8.227)$ & (11.092) & $(5.680)$ & (6.708) \\
\hline \multirow[t]{2}{*}{ ROA } & $-0.220^{* * *}$ & $-0.189^{* * *}$ & $-0.245^{* * *}$ & $-0.221^{* * *}$ & $-0.216^{* * *}$ \\
\hline & $(-26.780)$ & $(-19.227)$ & $(-24.825)$ & $(-21.71)$ & $(-22.38)$ \\
\hline \multirow[t]{2}{*}{ NWC } & $-0.102^{* * *}$ & $-0.105^{* * *}$ & $-0.090^{* * *}$ & $-0.105^{* * *}$ & $-0.106^{* * *}$ \\
\hline & $(-24.698)$ & $(-21.934)$ & $(-18.550)$ & $(-19.37)$ & $(-20.64)$ \\
\hline \multirow[t]{2}{*}{$C$} & $0.05^{* * *}$ & $0.040^{* * *}$ & $0.048^{* * *}$ & $0.06^{* * *}$ & $0.06^{* * *}$ \\
\hline & (10.88) & $(7.996)$ & $(9.106)$ & $(9.15)$ & $(9.970$ \\
\hline R-square & 0.28 & 0.348 & 0.349 & 0.20 & 0.20 \\
\hline Obs & 33,580 & 33,580 & 33,580 & 33,580 & 33,580 \\
\hline
\end{tabular}

Note: This table presents regression results of formal institutions and firm specific variables on cash holdings in respect of Asia Pacific for 33,580 observations from 15 countries. In column (1) of the table, regression results of EGLS (PCSE) are reported for the period 2007 to 2016 for reference purpose. In column (2), regression results of EGLS (PCSE) for the year 2007 to 2011 are stated. In column (3), regression results of EGLS (PCSE) for the year 2012 to 2016 are presented. Columns (4) and (5) report regression results of GMM and WLS methods respectively for the period 2007 to 2016. Winsorization of variables is made at the $5 \%$ level. All variables are defined in table A1. In parentheses, robust t-statistics are reported. ${ }^{*} \mathrm{P}<0.10 ;{ }^{* *} \mathrm{P}<0.05 ;{ }^{* * *} \mathrm{P}<0.01$.

For Europe, the signs of the coefficients of the formal institutions and firm specific variables, and their level of significance, are almost the same as the ones for the base regression presented in table A4. Similarly, 
for Asia pacific, the signs of the coefficients of SRI, equity market development and firm specific variables, and their level of significance, are almost the same as the ones for the base regression presented in tableA5. Only Worldwide Governance Index (WGI) turns to positive in WLS, although the value is still insignificant. Overall, the results of the WLS regression confirm the robustness of this study's findings of the base regression presented in table A4 and A5.

\section{Conclusions}

In this study, an investigation has been carried out, for the first time, to analyze the variation in cash holdings, in two important regions of the world i.e. Europe and Asia Pacific, for the period ranging between the years of 2007 to 2016. The results of the analysis in both the regions uncover some interesting facts about the relationship between formal institutions, and firm specific factors, and cash holdings in both the regions.

In Europe, the Shareholders' Right Index, and the Worldwide Governance Index have a negative influence on the cash holdings. Whereas, it must be noted that the financial market development is positively associated with cash holdings for European countries. On the contrary, in Asia Pacific, the Shareholders' Right Index is positively related to cash holdings, while the financial market development is negatively associated with cash reserves. Overall, the governance index has an insignificant effect on cash holdings in the Asia Pacific region.

The negative relationship of Shareholders' Right, and the overall governance with cash holdings in Europe, is in accordance with the Agency View. Moreover, the positive effect of the Shareholders' Right on cash reserves in Asia Pacific, is derived by the Shareholders' Power Hypothesis. Similarly, the positive relationship of the financial market development, with cash holdings in Europe, indicates that when it is relatively easier to raise funds, companies tend to hold more cash. This is also supportive of the Agency View. The negative relationship of the financial market development, with cash holdings in Asia Pacific, shows that the Shareholders' Power Hypothesis prevails in the region, and shareholders of the firms, in the countries with less developed markets, allow the managers to hoard more money in order to avoid the cost of raising funds.

In Europe and Asia Pacific regions, leverage, dividend, growth, profitability and networking capital cast a negative effect on cash holdings, 
while financial strength, and cash flows influence the cash reserves positively. This indicates the application of transaction, and precautionary motives, in both the regions. However, size and investments have a significantly negative effect on the cash holdings in Europe, whereas, the said, firm specific variables, have a significantly positive effect on the level of cash in Asia Pacific. This difference may be attributed to the application of the Agency View in Europe, and the prevalence of Shareholders' Power Hypothesis in the Asia Pacific region.

This study is the first endeavor of its kind to analyze the impact of firm specific variables, and formal institutions, on cash holdings across two important regions, including Europe and Asia Pacific. The results of this study may be helpful for international managers, and finance scholars. The application of different theories of finance, including the Pecking Order Theory, Tradeoff Theory, Shareholders' Rights Hypothesis and the FCF Hypothesis, in both regions of the world, are also analyzed in this study.

This research is critical for international managers and financial scholars, as it is the first study to make a comparison between Asia Pacific and Europe, with respect to the impact that the firm specific variables, and the formal institutions have on cash holdings. Different theories including Free Cash Flows (FCF), Shareholders' Right Hypothesis, and the Tradeoff Theory are analyzed to understand and extract the cash holding determinants.

The literature reveals that apart from the formal institutions, and firm specific factors, the national culture also has a pronounced impact on the level of cash holdings in a country or region. Future research may be carried out to analyze the effect of the national culture, along with the formal institutions and firm specific factors on cash holding decisions, not only limited to Europe and Asia Pacific, but also for the other regions of the world. This worldwide comparison promises to be very useful for the corporate practitioners, and finance scholars. 


\section{References}

Acharya, V. V., Almeida, H., \& Campello, M. (2007). Is cash negative debt? A hedging perspective on corporate financial policies. Journal of Financial Intermediation, 16(4), 515-554.

Akguc, S., \& Choi, J. J. (2013). Cash holdings in private and public firms: Evidence from Europe. Retrieved from http://sydney.edu.au/business/_data/assets/pdf_file/0006/170871/ Serkan_Cash_Holdings_PublicPrivateFirms_EvidencefromEurope _5_6_2013. pdf (4 de febrero de 2014).

Almeida, H., Campello, M., \& Weisbach, M. S. (2004). The cash flow sensitivity of cash. The Journal of Finance, 59(4), 1777-1804.

Amess, K., Banerji, S., \& Lampousis, A. (2015). Corporate cash holdings: Causes and consequences. International Review of Financial Analysis, $42,421-433$.

Al-Najjar, B., \& Belghitar, Y. (2011). Corporate cash holdings and dividend payments: Evidence from simultaneous analysis. Managerial and decision Economics, 32(4), 231-241.

Al-Najjar, B. (2013). The financial determinants of corporate cash holdings: Evidence from some emerging markets. International Business Review, 22(1), 77-88.

Al-Najjar, B., \& Clark, E. (2017). Corporate governance and cash holdings in MENA: Evidence from internal and external governance practices. Research in International Business and Finance, 39, 1-12.

Bates, T. W., Kahle, K. M., \& Stulz, R. M. (2009). Why do US firms hold so much more cash than they used to?. The Journal of Finance, 64(5), 1985-2021.

Bigelli, M., \& Sánchez-Vidal, J. (2012). Cash holdings in private firms. Journal of Banking \& Finance, 36(1), 26-35.

Caprio, L., Faccio, M., \& McConnell, J. J. (2011). Sheltering corporate assets from political extraction. The Journal of Law, Economics, $\mathcal{E}$ Organization, 29(2), 332-354. 
Chen, D., Li, S., Xiao, J. Z., \& Zou, H. (2014). The effect of government quality on corporate cash holdings. Journal of Corporate Finance, 27(August), 384-400.

Chen, Q., Chen, X., Schipper, K., Xu, Y., \& Xue, J. (2012). The sensitivity of corporate cash holdings to corporate governance. The Review of Financial Studies, 25(12), 3610-3644.

Chen, Y., Dou, P. Y., Rhee, S. G., Truong, C., \& Veeraraghavan, M. (2015). National culture and corporate cash holdings around the world. Journal of Banking \& Finance, 50(January), 1-18.

D'Mello, R., Krishnaswami, S., \& Larkin, P. J. (2008). Determinants of corporate cash holdings: Evidence from spin-offs. Journal of Banking E Finance, 32(7), 1209-1220.

Dittmar, A., Mahrt-Smith, J., \& Servaes, H. (2003). International corporate governance and corporate cash holdings. Journal of Financial and Quantitative analysis, 38(1), 111-133.

Dittmar, A., \& Mahrt-Smith, J. (2007). Corporate governance and the value of cash holdings. Journal of Financial Economics, 83(3), 599-634.

Djankov, S. (2009). The regulation of entry: A survey. The World Bank Research Observer, 24(2), 183-203.

Dudley, E., \& Zhang, N. (2016). Trust and corporate cash holdings. Journal of Corporate Finance, 41(Dec), 363-387.

Fan, J. P., Wong, T., \& Zhang, T. (2007). Organizational structure as a decentralization device: Evidence from Corporate Pyramids. Available at SSRN 963430.

Ferreira, M. A., \& Vilela, A. S. (2004). Why do firms hold cash? Evidence from EMU countries. European Financial Management, 10(2), 295-319.

Foley, C. F., Hartzell, J. C., Titman, S., \& Twite, G. (2007). Why do firms hold so much cash? A tax-based explanation. Journal of Financial Economics, 86(3), 579-607. 
Gao, H., Harford, J., \& Li, K. (2013). Determinants of corporate cash policy: Insights from private firms. Journal of Financial Economics, 109(3), 623-639.

García-Teruel, P. J., \& Martínez-Solano, P. (2008). On the determinants of SME cash holdings: Evidence from Spain. Journal of Business Finance \& Accounting, 35(1-2), 127-149.

Guizani, M. (2017). The financial determinants of corporate cash holdings in an oil rich country: Evidence from Kingdom of Saudi Arabia. Borsa Istanbul Review, 17(3), 133-143.

Guney, Y., Ozkan, A., \& Ozkan, N. (2003). Additional international evidence on corporate cash holdings, EFMA.

Harford, J., Mansi, S. A., \& Maxwell, W. F. (2008). Corporate governance and firm cash holdings in the US. Journal of financial economics, 87(3), 535-555.

Harford, J., Kecskés, A., \& Mansi, S. (2012). Investor horizons and corporate cash holdings. Available at SSRN 2000226.

Hill, M. D., Fuller, K. P., Kelly, G. W., \& Washam, J. O. (2014). Corporate cash holdings and political connections. Review of Quantitative Finance and Accounting, 42(1), 123-142.

Hoberg, G., Phillips, G., \& Prabhala, N. (2014). Product market threats, payouts, and financial flexibility. The Journal of Finance, 69(1), 293-324.

Huang, J., \& Kisgen, D. J. (2013). Gender and corporate finance: Are male executives overconfident relative to female executives?. Journal of Financial Economics, 108(3), 822-839.

Iskandar-Datta, M. E., \& Jia, Y. (2014). Investor protection and corporate cash holdings around the world: new evidence. Review of Quantitative Finance and Accounting, 43(2), 245-273.

Jensen, M. C. (1986). Agency costs of free cash flow, corporate finance, and takeovers. The American Economic Review, 76(2), 323-329.

Julio, B., \& Yook, Y. (2012). Political uncertainty and corporate investment cycles. The Journal of Finance, 67(1), 45-83. 
Kalcheva, I., \& Lins, K. V. (2007). International evidence on cash holdings and expected managerial agency problems. The Review of Financial Studies, 20(4), 1087-1112.

Kato, K., Li, M., \& Skinner, D. J. (2017). Is Japan Really a "Buy"? The Corporate Governance, Cash Holdings and Economic Performance of Japanese Companies. Journal of Business Finance \& Accounting, 44(3-4), 480-523.

Kaufmann, D., Kraay, A., \& Mastruzzi, M. (2011). The worldwide governance indicators: methodology and analytical issues. Hague Journal on the Rule of Law, 3(2), 220-246.

Khieu, H. D., \& Pyles, M. K. (2012).The influence of a credit rating change on corporate cash holdings and their marginal value. Financial Review, 47(2), 351-373.

Kusnadi, Y. (2011). Do corporate governance mechanisms matter for cash holdings and firm value?. Pacific-Basin Finance Journal, 19(5), 554-570.

Kusnadi, Y., Yang, Z., \& Zhou, Y. (2015). Institutional development, state ownership, and corporate cash holdings: Evidence from China. Journal of Business Research, 68(2), 351-359.

La Porta, R. L., Lopez-de-Silanes, F., Shleifer, A., \& Vishny, R. W. (1998). Law and finance. Journal of Political Economy, 106(6), 1113-1155.

La Porta, R., Lopez-de-Silanes, F., Shleifer, A., \& Vishny, R. (1999). The quality of government. The Journal of Law, Economics, and Organization, 15(1), 222-279.

Lins, K. V., Servaes, H., \& Tufano, P. (2010). What drives corporate liquidity? An international survey of cash holdings and lines of credit. Journal of Financial Economics, 98(1), 160-176.

Liu, Q., Luo, T., \& Tian, G. G. (2015). Family control and corporate cash holdings: Evidence from China. Journal of Corporate Finance, 31(April), 220-245.

Liu, Y., Mauer, D. C., \& Zhang, Y. (2014). Firm cash holdings and CEO inside debt. Journal of Banking \& Finance, 42(May), 83-100. 
Miller, M. H., \& Orr, D. (1966). A Model of the Demand for Money by Firms. The Quarterly Journal of Economics, 80(3), 413-435.

Myers, S. C., \& Majluf, N. S. (1984). Corporate financing and investment decisions when firms have information that investors do not have. Journal of Financial Economics, 13(2), 187-221.

Oler, D. K., \& Picconi, M. P. (2014). Implications of insufficient and excess cash for future performance. Contemporary Accounting Research, 31(1), 253-283.

Opler, T., Pinkowitz, L., Stulz, R., \& Williamson, R. (1999). The determinants and implications of corporate cash holdings. Journal of financial economics, 52(1), 3-46.

Ozkan, A., \& Ozkan, N. (2004). Corporate cash holdings: An empirical investigation of UK companies. Journal of Banking \& Finance, 28(9), 2103-2134.

Pinkowitz, L., Stulz, R. M., \& Williamson, R. (2015). Do US firms hold more cash than foreign firms do?. The Review of Financial Studies, 29(2), 309-348.

Qiu, J., \& Wan, C. (2015). Technology spillovers and corporate cash holdings. Journal of Financial Economics, 115(3), 558-573.

Rehman, A., \& Wang, M. (2015). Corporate cash holdings and adjustment behavior in Chinese firms: An empirical analysis using generalized method of moments. Australasian Accounting Business \& Finance Journal, 9(4), 20.

Stiglitz, J. E. (1974). On the irrelevance of corporate financial policy. The American Economic Review, 64(6), 851-866.

Subramaniam, V., Tang, T. T., Yue, H., \& Zhou, X. (2011). Firm structure and corporate cash holdings. Journal of Corporate Finance, 17(3), 759-773.

Weidemann, J. F. (2016). The determinants of cash holdings: Evidence from meta-regression analysis. In Proceedings EFMA 2016 Conference. 